\title{
Stimulatory actions of lysophosphatidic acid on mouse ATDC5 chondroprogenitor cells.
}

\section{AUTHOR(S):}

Itoh, Ryota; Miura, Shigenori; Takimoto, Aki; Kondo, Shunya; Sano, Hiroko; Hiraki, Yuji

\section{CITATION:}

Itoh, Ryota ...[et al]. Stimulatory actions of lyso phosphatidic acid on mouse ATDC5

chondroprogenitor cells.. Journal of bone and mineral metabolism 2010, 28(6): 659-671

\section{ISSUE DATE:}

2010-11

URL:

http://hdl.handle.net/2433/131935

\section{RIGHT:}

The final publication is available at www.springerlink.com; This is not the published version. Please cite only the published version.; この論文 は出版社版でありません。引用の際には出版社版をご確認ご利用くだ さい。 
Ryota Itoh, Shigenori Miura, Aki Takimoto, Shunya Kondo, Hiroko Sano, Yuji Hiraki

Stimulatory actions of lysophosphatidic acid on mouse ATDC5 chondroprogenitor cells

R. Itoh, S. Miura, A. Takimoto, S. Kondo, H. Sano, Y. Hiraki (®)

Department of Cellular Differentiation, Institute for Frontier Medical Sciences, Kyoto University, Sakyo-ku, Kyoto 606-8507, Japan.

e-mail: hiraki@frontier.kyoto-u.ac.jp 
Abstract Lysophosphatidic acid (LPA) and sphingoshine-1-phosphate (S1P) are bioactive lysophospholipids which affect various cellular processes through G protein-coupled receptors. In our current study, we found by in situ hybridization that E11.5 mouse embryos strongly expressed the LPA receptor subtype $\mathrm{LPA}_{1}$ in cartilaginous bone primordia and the surrounding mesenchymal cells. However, despite their wide-ranging actions, the roles of lysophospholipids in chondrogenesis remain poorly understood. The mouse clonal cell line ATDC5 undergoes a sequential differentiation of chondroprogenitor cells in vitro. Undifferentiated and differentiated ATDC5 cells express $\mathrm{LPA}_{1}$ and other lysophospholipid receptors including S1P receptor $\mathrm{S}_{1} \mathrm{P}_{1}$ and $\mathrm{S}_{1} \mathrm{P}_{2}$. Taking advantage of this cell model, we studied the effects of LPA on the activities of chondroprogenitor cells. LPA markedly stimulates both DNA synthesis and the migration of ATDC5 chondroprogenitor cells in culture, whereas S1P suppresses the migration of these cells. Treatment with Ki16425, an $\mathrm{LPA}_{1}$ - and $\mathrm{LPA}_{3}$-specific receptor antagonist, suppressed the fetal bovine serum-stimulated migration of ATDC5 cells by almost $80 \%$. These results indicate that LPA plays an important role in the activation of chondroprogenitor cells.

Key words: ATDC5 cells, lysophosphatidic acid, sphingoshine-1-phosphate, cell migration, chondroprogenitor cells 


\section{Introduction}

Endochondral bone formation begins with the migration and condensation of chondroprogenitor cells. Subsequent overt chondrogenesis provides a cartilaginous mold for bone formation in mammals [1-3]. It has been shown that autotaxin (ATX), a tumor cell motility-stimulating factor [4,5], is abundantly expressed in the condensing mesenchyme of the future vertebra and also in the epiphyseal region of the developing limb in mouse and chick embryos [6,7]. This suggests a physiological role of lysophosphatidic acid (LPA) at these sites during skeletal development, since ATX has been identified as a secreted lysophospholipase D and plays a principal role in LPA production in the body $[8,9]$. However, ATX null mice exhibit lethality at around E10.5 as a result of severe defects in vascular development prior to skeletal development $[10,11]$. This lethal phenotype hampers the analysis of the roles of LPA signaling in chondrogenesis in vivo.

The endothelial differentiation gene (Edg) family of $G$ protein-coupled receptors (GPCRs) is a structurally related subfamily of the LPA and sphingoshine-1-phosphate (S1P) receptors, comprising three LPA receptors $\left(\mathrm{LPA}_{1-3}\right)$ and five S1P receptors $\left(\mathrm{S}_{1} \mathrm{P}_{1-5}\right)$, which are thought to transmit both distinct and overlapping signals [12-15]. The recently identified non-EDG family LPA receptors, $\mathrm{LPA}_{4} / \mathrm{p} 2 \mathrm{y} 9$ [16], $\mathrm{LPA}_{5} / \mathrm{GPR} 92[17,18], \mathrm{LPA}_{6} / \mathrm{GPR} 87$ [19], $\mathrm{LPA}_{7} / \mathrm{p} 2 \mathrm{y} 5$ [20,21], and $\mathrm{LPA}_{8} / \mathrm{p} 2 \mathrm{y} 10$ [22], are more closely related to the purinoreceptor gene cluster and share less than $20 \%$ amino acid identity with EDG-LPA receptors. Gene-targeting studies for EDG family LPA receptors have revealed roles for these signals in physiological processes: $\mathrm{LPA}_{1}$-deficient mice exhibit abnormal sucking behavior after birth and nearly $50 \%$ of 
these animals die at this stage [23]. Surviving mice show defects in craniofacial development and have a short nose, indicating a role for $\mathrm{LPA}_{1}$ in both craniofacial and neural crest development. ${\mathrm{S} 1 \mathrm{P}_{1}}_{1}$ signaling has also been suggested to function in limb development $[24,25]$. Kim and colleagues have reported that LPA stimulates cell migration and the proliferation of rat primary chondrocytes [26,27], whilst Facchini et al have shown that LPA inhibits the proliferation of immortalized human juvenile costal chondrocytes [28]. However, little is still known about the actions of LPA on chondroprogenitor cells.

We have previously demonstrated that the mouse clonal cell line ATDC5 retains the properties of chondroprogenitors [29,30]: Undifferentiated ATDC5 cells adopt a fibroblastic morphology in sparse cultures, and rapidly proliferate in the presence of $5 \%$ fetal bovine serum (FBS) to form a confluent monolayer and cease growth due to contact inhibition [29]. In the presence of $10 \mu \mathrm{g} / \mathrm{ml}$ insulin, ATDC5 cells with an elongated spindle-like morphology appear to form areas of cellular condensation [29]. Subsequently, differentiated chondrocytes with a rounded morphology appear in the condensation areas and re-enter the growth state with a longer cell doubling time to form cartilage nodules. As cartilage nodules expand with the growth of chondrocytes and accumulation of cartilage matrix, cells in the depth of the cartilage nodules become hypertrophic with the expression of type X collagen [30]. In our current study, we report the effects of LPA on the behavior of ATDC5 chondroprogenitor cells in vitro. 


\section{Materials and methods}

\section{Materials}

LPA, pertussis toxin (PTX), Ki16425, sodium selenite, and fatty acid-free bovine serum albumin (BSA) were purchased from Sigma (St. Louis, MO). Human insulin, and human transferrin were obtained from Roche (Mannheim, Germany). DMEM/F12 and aMEM were purchased from Mediatech Inc. (Herndon, VA) and Sigma (St. Louis, MO), respectively. S1P was obtained from BIOMOL (Plymouth Meeting, PA). Stock solutions of LPA and S1P were prepared in 1\% BSA/PBS. Ki16425 was dissolved in dimethyl sulfoxide (DMSO) and added to the cell cultures at a 1000-fold dilution. LY294002 and Y-27632 were purchased from Calbiochem (LA Jolla, CA). U0126 was obtained from Cell Signaling Technology (Beverly, MA). Recombinant human fibroblast growth factor-2 (FGF-2), human platelet-derived growth factor-BB (PDGF-BB) and mouse insulin-like growth factor-I (IGF-I) were sourced from R\&D Systems (Minneapolis, $\mathrm{MN})$. Bromo-2'-deoxyuridine (BrdU) and BrdU labeling kit III were obtained from Roche (Mannheim, Germany). The phosphoPlus p44/42 MAP kinase (Thr202/Tyr204) antibody Kit was purchased from Cell Signaling (Danvers, MA). Anti-RhoA mouse monoclonal antibody and Rhotekin-RBD agarose beads were purchased from Santa Cruz Biotechnology (Santa Cruz, CA) and Millipore (Temecula, CA), respectively.

Cell culture

Undifferentiated ATDC5 chondroprogenitor cells were grown at the initial seeding density of $3 \times 10^{5}$ cells in T75 flasks and maintained at a subconfluent or lower cell density in DMEM/F12 supplemented with 5\% FBS and ITS $(10 \mu \mathrm{g} / \mathrm{ml}$ human insulin 
(I), $10 \mu \mathrm{g} / \mathrm{ml}$ human transferrin (T) and $3 \times 10^{-8} \mathrm{M}$ sodium selenite $\left.(\mathrm{S})\right)$ at $37^{\circ} \mathrm{C}$ under $5 \% \mathrm{CO}_{2}$ in air $[29,31]$. Every third day, subconfluent cultures were trypsinized and a portion of the harvested cells were used in subsequent experiments: cells were plated at $2 \times 10^{4}$ cells/well in 24 -multiwell plates, $4 \times 10^{4}$ cells/well in 12 -multiwell plates, or 6 $\times 10^{4}$ cells/well in 6-multiwell plates in the same medium. Cultures reached confluence on day 3 . On day 17 , the culture medium was replaced with $\alpha$ MEM containing $5 \%$ FBS and ITS under $3 \% \quad \mathrm{CO}_{2}$ to facilitate cellular hypertrophy and mineralization. DMEM/F12 containing Ki16425 was used in some experiments. The culture medium was replaced every other day.

Northern blot hybridization

ATDC5 cells were plated at $6 \times 10^{4}$ cells/well in 6 -multiwell plates and cultured for the appropriate number of days and tissues were dissected from 11 week-old (testis, lung, and kidney) or 3 week-old (rib cartilage) ICR male mice. Total RNA was extracted from cultured ATDC5 cells or from the dissected tissues using the single-step method [32], resolved on $1 \%$ agarose-formaldehyde gels, and transferred to Nytran membranes using Turboblotter (Schleicher and Schuell, Dassel, Germany). To prepare hybridization probes, first strand cDNA was synthesized with SuperScript II RNase $\mathrm{H}^{-}$reverse transcriptase (Gibco BRL, Grand Island, NY), and RT-PCR was performed using the primer sets listed in Table 1. The amplified cDNA fragments were subcloned into the pCRII-TOPO vector (Invitrogen, Carlsbad, CA), sequenced, and then labeled with $\left[\alpha-{ }^{32} \mathrm{P}\right] \mathrm{dCTP}$ (Amersham Biosciences, Piscataway, NJ) via the random-primer method with a BcaBEST labeling kit (Takara, Shiga, Japan). The cDNA fragments used for the synthesis of $\alpha 1$ (II) collagen and $\alpha 1(\mathrm{X})$ collagen probes were prepared from $\mathrm{pKT} 1180$ 
[33] and pSAm10h [34], respectively. Hybridization was performed overnight at $42^{\circ} \mathrm{C}$ with an appropriate probe in a solution containing 50\% formamide, $6 \times \mathrm{SSPE}, 0.1 \%$ BSA, $0.1 \%$ Ficoll 400, 0.1\% polyvinylpyrrolidone, 0.5\% SDS and $100 \mu \mathrm{g} / \mathrm{ml}$ denatured salmon sperm DNA. The membranes were washed three times at $55^{\circ} \mathrm{C}$ for $20 \mathrm{~min}$ in $0.1 \%$ SDS, $0.1 \times$ SSPE and exposed to BioMax MS Film (Carestream Health, Rochester, $\mathrm{NY}$ ) at $-80^{\circ} \mathrm{C}$. A quantitative analysis of hybridization signals was performed by scanning densitometry of autoradiograph using Fuji Film Science Lab 99 Image Gauge ver. 3.4 software (Fuji Photo Film, Tokyo, Japan).

In situ hybridization

Antisense and sense (control) riboprobes for each gene were prepared using a digoxygenin (DIG) RNA labeling kit (Roche) using appropriate cDNA fragments. E11.5 embryos of ICR mice were dissected from female mice, embedded in OCT compound (Sakura Finetek \& Tissue-Tek, Tokyo, Japan). Sections of $12-\mu \mathrm{m}$-thickness were mounted onto microscope slides, air-dried at $50^{\circ} \mathrm{C}$ and fixed briefly with $4 \%$ paraformaldehyde. Hybridization was performed at $58^{\circ} \mathrm{C}$ for $16 \mathrm{~h}$ with an appropriate probe in a solution containing $50 \%$ formamide, $5 \times \mathrm{SSC}$ and $40 \mu \mathrm{g} / \mathrm{ml}$ salmon sperm DNA. Following washing under high stringency conditions, DIG-labeled molecules were visualized using BM purple (Roche) as the substrate for anti-DIG antibody-coupled alkaline phosphatase.

DNA synthesis and cell proliferation assays

ATDC5 cells were plated at $5 \times 10^{3}$ cells/well in 96-multiwell plates, grown in DMEM/F12 containing 5\% FBS and ITS for three days to confluence, and preincubated with DMEM/F12 containing 0.1\% BSA with or without $100 \mathrm{ng} / \mathrm{ml}$ PTX for $24 \mathrm{~h}$. The 
cultures were then treated with various concentrations of different factors for $24 \mathrm{~h}$. Cells were labeled with $1 \mathrm{nmol} / \mathrm{ml} \mathrm{BrdU}$ for the last $4 \mathrm{~h}$ of this incubation. Incorporation of BrdU into DNA was determined using a BrdU labeling kit III (Roche) in accordance with the manufacturer's instructions. Absorbances at $405 \mathrm{~nm}$ were measured with a Model 450 Microplate Reader (Bio-Rad, Hercules, CA).

For the determination of growth response of confluent ATDC5 cells, the cells $\left(4 \times 10^{4}\right.$ cells/well $)$ were plated in 12-multiwell plates and grown to confluence in DMEM/F12 containing 5\% FBS. The cells were preincubated with DMEM/F12 containing $0.3 \%$ FBS for $24 \mathrm{~h}$. The medium was then replaced by the same medium with test samples. After $36 \mathrm{~h}$, the number of cells in each well was counted with a hemocytometer after trypsinization.

Western blotting analysis of ERK1/2 phosphorylation

Confluent ATDC5 cells were preincubated for $6 \mathrm{~h}$ in DMEM/F12 containing $0.1 \%$ BSA in 12-multiwell plates. In some experiments, the cells were preincubated with $100 \mathrm{ng} / \mathrm{ml}$ PTX for the last $4 \mathrm{~h}$. The culture medium was then replaced by DMEM/F12 containing $0.1 \% \mathrm{BSA}$, and the cells were incubated with various concentrations of LPA with or without Ki16425 for the indicated times. After incubation, the cells were immediately rinsed with PBS, and lysed with SDS sample buffer. The resultant cell lysates were boiled for $5 \mathrm{~min}$ and separated using 12\% SDS-PAGE gels, and transferred onto nitrocellulose membrane (Bio-Rad, Hercules, CA). The membranes were preincubated with $3.2 \%$ skim milk in Tris buffered saline for 20 min and analyzed by a PhosphoPlus p44/42 MAP kinase (Thr202/Tyr204) antibody kit in accordance with the manufacturer's instructions. 
Cell migration assay

The transwell migration of ATDC5 cells was determined using a modified Boyden chamber assay. Both sides of an 8- $\mu$ m-pore migration chamber (24-well format; Becton Dickinson, Franklin Lakes, NJ) were coated with $50 \mu \mathrm{g} / \mathrm{ml}$ type I collagen at $4^{\circ} \mathrm{C}$ overnight, air-dried and washed twice with PBS prior to plating the cells. The cells were harvested and washed twice with migration medium (DMEM/F12 containing $0.1 \%$ BSA and ITS). Cells $\left(5 \times 10^{4}\right)$ suspended in $300 \mu$ of the migration medium were seeded in the top well of the chamber and allowed to migrate for $4 \mathrm{~h}$ at $37^{\circ} \mathrm{C}$ under $5 \% \mathrm{CO}_{2}$ in air toward the bottom well filled with $600 \mu$ of the migration medium containing various factors. In some experiments, ITS was omitted from the migration medium. Various concentrations of Ki16425 were added in the migration medium in the top well of the chamber in some assays. LY294002, U0126, and Y-27632 were added to both of the chambers and preincubated with cells for $30 \mathrm{~min}$ at $37^{\circ} \mathrm{C}$ prior to seeding. The cells were fixed with 4\% paraformaldehyde and stained with Dif Quick (Sysmex, Kobe, Japan). The non-migrated cells on the top well were removed with a cotton swab, and the migrated cells on the bottom of the chamber were photographed under a light microscope at a magnification of $\times 200$ and counted in four randomly selected fields.

LPA1 knockdown by RNA interference

Small interfering RNA (siRNA) oligonucleotide duplexes were purchased from Dharmacon (Lafayette, CO). LPA 1 were knocked down using a pool of four siRNA duplexes (siGENOME SMART pool, M-043497-01-0005) and siGENOME Non-Targeting siRNA Pool \#1 (D-001206-13-05) was used for control experiment. Transfection of siRNA into ATDC5 cells was performed by electroporation using 
Amaxa Nucleofector system (Amaxa, Gaithersburg, MD) according to the manufacture's instructions. Briefly, subconfluent cells were harvested and $1 \times 10^{6}$ cells were resuspended in $100 \mu \mathrm{l}$ of Nucleofector solution T. LPA 1 or non-targeting siRNA (100 pmol) was added to the cell suspension and cells were electroporated with program T-020. The cells were immediately resuspended in DMEM/F12 supplemented with 5\% FBS and ITS, plated onto 6-multiwell plates. After $24 \mathrm{~h}$, total RNA was extracted, reverse-transcribed using SuperScript II RNase $\mathrm{H}^{-}$reverse transcriptase (Gibco BRL, Grand Island, NY). Efficiency of LPA 1 knockdown was evaluated by RT-PCR analysis using primer sets listed in Table I. Amplification of glyceraldehyde-3-phosphate-dehydrogenase (GAPDH) was utilized as an internal control and the primer sequences used were as follows: GAPDH forward primer: 5'-ACCACAGTCCATGCCATCAC-3'; GAPDH reverse primer: 5'-TCCACCACCCTGTTGCTGTA-3'.

Immunofluorescence microscopy

ATDC5 cells grown on Lab-Tek II glass CC2 chamber slides (Nalgen Nunc International, Naperville IL) were incubated for $6 \mathrm{~h}$ in DMEM/F12 containing $0.1 \%$ $\mathrm{BSA}$, and stimulated with or without $100 \mathrm{nM} \mathrm{LPA}$ at $37^{\circ} \mathrm{C}$ for the last $30 \mathrm{~min}$ in the presence or absence of $3 \mu \mathrm{M}$ Ki16425. The cells were then fixed with $4 \%$ paraformaldehyde for $10 \mathrm{~min}$ and permeabilized with $0.2 \%$ Triton X-100 for a further 4 min. After blocking in 5\% skim milk/PBS for $30 \mathrm{~min}$, cells were incubated with anti-paxillin mouse IgG (BD transduction laboratories, San Jose, CA) at $4^{\circ} \mathrm{C}$ overnight, followed by incubation for $1 \mathrm{~h}$ with a mixture of Alexa Fluor 594-conjugated phalloidin (Invitrogen), Alexa Fluor 488-conjugated anti mouse IgG (Invitrogen) and $1 \mu \mathrm{g} / \mathrm{ml}$ 
DAPI (Sigma). Coverslips were mounted on glass chamber slides using Prolong Gold (Invitrogen) and examined by fluorescence microscopy (Leica Microsystems, Mannheim, Germany).

RhoA pull-down assay

ATDC5 cells were plated at $5 \times 10^{5}$ cells in $100-\mathrm{mm}$ culture dishes, and grown to confluence. The confluent cultures were then preincubated in DMEM/F12 containing $0.1 \%$ BSA for $6 \mathrm{~h}$, stimulated with various concentrations of LPA for $2 \mathrm{~min}$, immediately rinsed with ice-cold PBS, and then lysed with ice-cold lysis buffer containing 1\% Igepal CA-630, 25 mM HEPES (pH 7.5), 150 mM NaCl, 10\% glycerol, $10 \mathrm{mM} \mathrm{MgCl}$, $1 \mathrm{mM}$ EDTA, $10 \mu \mathrm{g} / \mathrm{ml}$ leupeptin, and $10 \mu \mathrm{g} / \mathrm{ml}$ aprotinin. Lysates were incubated at $4^{\circ} \mathrm{C}$ for 20 min and clarified by centrifugation. Aliquots of clarified lysates were then denatured in SDS sample buffer and used for the analysis of total RhoA levels. For pull-down assays, lysates were incubated with $25 \mu \mathrm{g}$ of Rhotekin-RBD agarose beads (Millipore, Temecula, CA) for $1 \mathrm{~h}$ at $4^{\circ} \mathrm{C}$. The beads were rinsed three times with the lysis buffer and bound proteins were eluted by boiling in $30 \mu \mathrm{l}$ of SDS sample buffer. Samples were separated in $12 \%$ SDS-PAGE and subjected to western blot analysis using a mouse monoclonal antibody against RhoA (Santa Cruz Biotechnology Inc., Santa Cruz, CA).

\section{Alcian blue staining}

Cells were rinsed with PBS, fixed with 95\% methanol for 20 minutes, air-dried and stained with $0.1 \%$ Alcian blue 8 GS (Fluka, Buchs, Switzerland) in $0.1 \mathrm{M} \mathrm{HCl}$ overnight at room temperature. The stained wells were photographed and the Alcian blue positive regions per well were examined using NIH image. 


\section{Results and Discussion}

The lysophosphatidic acid receptor $\mathrm{LPA}_{1}$ is expressed in chondrogenic cells

Since the LPA receptor subtype $\mathrm{LPA}_{1}$ has been shown to mediate the signals underlying LPA activities in many cell types [35], we studied the expression pattern of the lysophosphatidic acid receptor $\mathrm{LPA}_{1}$ at an early stage of skeletal development in mouse embryos at E10.5 and E11.5 by in situ hybridization (Figs. 1 and 2). $L P A_{1}$ was expressed in the cartilaginous elements of vertebrae (Figs. 1A, C, and E, arrowheads) that expressed type II collagen, and diffusely expressed in the mesenchymal cells surrounding axial skeletal elements. The region of $L P A_{1}$ expression was found to be overlapped with Sox9-positive prechondrogenic region (Fig. 1C, also expressed in neural tube) and also Paxl-positive sclerotome compartment (Fig. 1D, dotted circles) from which mesenchymal cells migrate to form vertebral body [36,37]. The intense expression of ATX was found in the floor plate of neural tube (Fig. 1F). Some regions surrounding the floor plate including $L P A_{1}$-expressing prechondrogenic regions were also found to express ATX, although the detected hybridization signals were faint but clearly positive. Thus the ATX-positive LPA-production domains in embryos seem to localize within or close enough to the Sox9- or Paxl-positive prechondrogenic regions and cartilaginous primordia, which are also $\mathrm{LPA}_{1}$-positive. At E11.5, $L P A_{1}$ transcripts were more clearly localized to the cartilaginous bone primordia of the vertebrae (Figs. $2 \mathrm{~A}$ and E), particularly in the posterior regions of the vertebrae that overlap with the expression domain of $A T X[6,7]$. In addition to these sites, $\mathrm{LPA}_{1}$ transcripts were evident in the medial nasal process, the mandibular compartment of first and second branchial arches, and other structures (Fig. 2A), implicating LPA $_{1}$ signaling in 
chondrogenesis during skeletal development. Expression of other $L P A$ and $S 1 P$ receptor subtypes was less evident.

To further study the role of lysophospholipid in chondrogenesis in vitro, we examined the expression of some of the known lysophospholipid receptors, including $L P A_{1-3}$ and $S 1 P_{1-3}$, during chondrogenic differentiation in mouse ATDC5 cells. Northern blot analysis revealed that undifferentiated ATDC5 chondroprogenitor cells expressed transcripts for LPA and S1P receptors on day 3 (Fig. 3). Notably, the levels of $L P A_{1}$ transcripts were prominent compared with other known tissues that express this receptor subtype including the adult mouse testis and lung [38], and comparable to those in rib cartilage. The $L P A_{1}$ levels were high in ATDC5 cells at the undifferentiated and condensation stage (days 3 and 7, respectively), and decreased with the progression of chondrogenic differentiation as characterized by the induction of type II collagen transcripts (days 14 and 17). The expression of $L P A_{l}$ transcripts increased again during the hypertrophy/calcification stages (days 26 and 42) as characterized by an abundant expression of type $\mathrm{X}$ collagen transcripts. $L P A_{2}$ transcripts were also detected, but $L P A_{3}$ was not evident (Fig. 3). Transcripts for all three S1P receptors $\left(\mathrm{S}_{1} \mathrm{P}_{1-3}\right)$ were detected in undifferentiated ATDC5 chondroprogenitor cells (day 3). However, the cells mainly expressed $\mathrm{SIP}_{2}$ transcripts at a level comparable to that in mouse lung, which is known to express transcripts for all three S1P receptors $\left(S 1 P_{1-3}\right)$ [39]. No significant changes were observed in the levels of $S 1 P_{1}$ or $S 1 P_{2}$ transcripts during differentiation. These results indicate the possibility that ATDC5 cells can respond to lysophospholipids through their cognate receptors. Among others, LPA 1 may play a role in chondrogenesis. 
LPA stimulates DNA synthesis in ATDC5 chondroprogenitor cells

Quiescent cultures of undifferentiated ATDC5 cells were treated with LPA or S1P for 24 $\mathrm{h}$ and the rate of DNA synthesis was assessed by BrdU incorporation during the last $4 \mathrm{~h}$ of the incubation period. LPA was found to stimulate DNA synthesis in ATDC5 cells in a dose-dependent manner (Fig. 4A). LPA $(10 \mu \mathrm{M})$ also increased BrdU incorporation by about 6-fold compared with the control, whereas S1P had little effect (Fig. 4B). The stimulatory effects of LPA were blocked when the cells were pretreated with the Gi-specific inhibitor PTX, indicating that the effects of LPA are GPCR-mediated. For comparison, the same cells were treated with FGF-2 $(1 \mathrm{ng} / \mathrm{ml})$ as a positive control for growth stimulation and BrdU incorporation was increased by about 10 -fold ( $955 \pm 45 \%$ and $978 \pm 100 \%$ of control in the absence and presence of $100 \mathrm{ng} / \mathrm{ml} \mathrm{PTX}$, respectively). In agreement with an increase in DNA synthesis, a $1 \mathrm{ng} / \mathrm{ml}$ concentration of FGF-2 increased the cell number in confluent cultures of ATDC5 cells by about 1.8 -fold over the control (Fig. 4C). In comparison, $10 \mu \mathrm{M}$ LPA moderately stimulated proliferation of cells and the cell number increased by 1.3 -fold (Fig. 4C). Hence, we next examined the activation of a MAPK pathway.

In quiescent ATDC5 cells in confluent culture, LPA $(0.1 \mu \mathrm{M})$ appeared to stimulate the phosphorylation of ERK1/2 within 5 min, and phosphorylated ERK1/2 (p-ERK1/2) was reduced to basal levels within 10 min (Fig. 4D). As shown in Figure 4E, the levels of p-ERK1/2 were increased by the LPA treatment in a dose-dependent manner. This stimulation of ERK1/2 phosphorylation was abolished by PTX, suggesting that the $\mathrm{G}_{\mathrm{i}}$-ERK pathway plays a role in the LPA-induced activation of ATDC5 cells. The LPA-induced phosphorylation of ERK1/2 was also abrogated by the LPA receptor 
antagonist Ki16425 $(3 \mu \mathrm{M})$ which preferentially blocks $\mathrm{LPA}_{1}$ and $\mathrm{LPA}_{3}$ signaling [40] (Fig. 4E).

LPA markedly stimulates the migration of ATDC5 chondroprogenitor cells

The effects of LPA and S1P upon the transwell migration of undifferentiated ATDC5 cells were examined. S1P appeared to inhibit cell migration to below the control levels at $0.1-1 \mu \mathrm{M}$, even though this effect was not statistically significant (Fig. 5A). In contrast, as shown in Figure 5A, LPA markedly stimulated migration and produces a bell-shaped dose-response curve. These stimulatory effects were evident at a concentration of only $0.001 \mu \mathrm{M}$, reached maximal levels at around $0.1 \mu \mathrm{M}$, and decreased to basal levels at $10 \mu \mathrm{M}$. The stimulatory effects of LPA were completely abolished by PTX pretreatment of the cells (Fig. 5B), and attenuated in the presence of PI3K selective inhibitor (LY294002), but not MEK1/2 inhibitor (U0126) and Rho kinase inhibitor (Y-27632) (Fig. 5C). These experiments suggest that the $\mathrm{G}_{\mathrm{i}}-\mathrm{PI} 3 \mathrm{~K}$ signaling pathway plays a critical role in the stimulatory phase of a LPA effect on ATDC5 cells.

As shown in Figure 5D, the LPA-induced migration of ATDC5 cells was suppressed by Ki16425 in a dose-dependent manner. Moreover, the stimulatory effects of $0.1 \mu \mathrm{M}$ LPA were almost completely abrogated by Ki16425 at a concentration of 1 $\mu \mathrm{M}$ or higher. The micromolar range of LPA has been reported to monotonically stimulate the migration of mesenchymal stem cells as well as primary chondrocytes [27,41]. Hence, the treatment of these cell-types with $10 \mu \mathrm{M}$ LPA results in a remarkable stimulation of migration. In contrast, ATDC5 cells showed almost no migratory activity in response to $10 \mu \mathrm{M}$ LPA. However, the migration of ATDC5 
chondroprogenitor cells was markedly stimulated in response to a lower concentration of LPA $(0.01-1 \mu \mathrm{M})($ Fig. 5A) [27,41]. In this respect, ATDC5 cells are sensitive to LPA upon migration. The bell-shaped dose-response profile appears to be characteristic of ATDC5 chondroprogenitor cells, suggesting that a unique mode of regulation may operate in the cells.

Cell migration involves dynamic and spatial changes in cytoskeleton and cell adhesion. In contrast to the polygonal cells in the control culture (Fig. 5E, panel 1), 0.1 $\mu \mathrm{M}$ LPA was found to markedly induce the formation of actin stress fibers and focal adhesions with active lamellipodial extensions in ATDC5 cells (Fig. 5E, panel 2). This effect on the actin cytoskeletal reorganization was abolished by $3 \mu \mathrm{M}$ Ki16425 (Fig. 5E, panel 3). Cells treated with a higher dose of LPA $(10 \mu \mathrm{M})$ adopted a less-extended shape and appeared to be smaller in size and less motile (Fig. 5E, panel 4). In these cases, most of the lamellipodial extensions were retracted and actin stress fibers became less evident. It has been shown that the Rho GTPases play key roles in coordinating the cellular responses required for cell migration $[42,43]$. The driving force for migration is generated by the extension of lamellipodia, the formation of new adhesion sites at the migrating front, and cell body contraction with tail detachment of the adhesions. As suggested in previous studies $[42,43]$, Rho has a particular role in cell body contraction. As shown in Fig. 5F, $0.1 \mu \mathrm{M}$ LPA caused only a marginal effect on the level of active GTP-RhoA. However, the higher doses of LPA (up to $10 \mu \mathrm{M}$ ) increased the level of active GTP-RhoA (Fig. 5F), which was consistent with the result shown in Fig. 5C of the Y-27632 treatment on cells stimulated by a low dose of LPA $(0.1 \mu \mathrm{M})$, and may cause increased cytoskeletal contraction in the cells. Interestingly, this dose-range of 
LPA $(0.1$ to $10 \mu \mathrm{M})$ coincided with the inhibitory phase of the bell-shaped dose-response profile of LPA actions upon cell migration (Fig. 5A). Total RhoA levels were not affected by the LPA treatment and appeared to be constant.

Utilising RNA interference technology, we then ablated the expression of $L P A_{1}$ receptor, which was predominantly expressed in ATDC5 cells (Fig. 3). Transfection of LPA1 siRNA selectively reduced the expression of $L P A_{1}$ within $24 \mathrm{~h}$ as shown by RT-PCR analysis (Fig. 6A). The level of $L P A_{1}$ transcripts was also evaluated by northern blot analysis and found to be less than $25 \%$ compared with that of control cells (data not shown). As shown in Fig. 6B, knockdown of $L P A_{1}$ expression markedly impaired the migration of cells toward LPA (Fig. 6B), indicating that $\mathrm{LPA}_{1}$ receptor signaling is critically important for LPA-induced migration of ATDC5 cells.

The LPA receptor antagonist Ki16425 suppresses the serum-induced migration of ATDC5 chondroprogenitor cells

Serum contains LPA at levels of around 1-5 $\mu \mathrm{M}$, in addition to various related factors $[44,45]$. Fetal bovine serum is required for the maintenance of ATDC5 chondroprogenitor cells, which are cultured in medium containing 5\% FBS under standard conditions. To elucidate a role for serum LPA in the regulation of ATDC5 cells, we examined the effects of the LPA receptor antagonist Ki16425 upon these cultures. ATDC5 cells grown in culture medium containing 5\% FBS showed a remarkable increase (132-fold over basal) in chemotactic migration, but LPA $(0.1 \mu \mathrm{M})$ treatment resulted in 65-fold increase in these levels (Fig. 7A). In addition, serum growth factors such as PDGF-BB (25 ng/ml; 4-fold increase) and IGF-I (100 ng/ml; 10-fold increase) were also capable of stimulating the migration of ATDC5 cells, whilst FGF2 (20 ng/ml) 
did not show this capacity (Fig. 7B). Although $3 \mu \mathrm{M}$ Ki16425 completely suppressed LPA-induced migration (Figs. 5D and 7A), it did not affect the action of IGF-I or of PDGF-BB (Fig. 7B). About 70\% of the FBS-stimulated increase of migration was found to be Ki16425-sensitive (Fig. 7A), suggesting that LPA is primarily responsible for the FBS-induced migration of these cells. IGF-I and/or PDGF in serum may thus account for the residual Ki16425-insensitive activity (about 30\% of the activity in FBS).

LPA receptor antagonist Ki16425 suppresses chondrogenic differentiation of ATDC5 cells

When cultured in 5\% FBS in the presence of $10 \mu \mathrm{g} / \mathrm{ml}$ insulin, ATDC5 cells undergo chondrogenic differentiation through the condensation stage after confluence (usually from day 3 to day 6 of culture under standard conditions) to form cartilage nodules that are rich in Alcian blue-positive cartilaginous extracellular matrix $[29,46]$. In the present study, we assessed the contribution of LPA in serum to chondrogenic differentiation of ATDC5 cells cultured in DMEM/F12 medium containing 5\% FBS and ITS by adding Ki16425 from day 3, since serum-free chondrogenic culture of ATDC5 cells is not possible so far. On day 17, the cultures were fixed and stained with Alcian blue. As shown in Figs. 8A and 8B, Kil6425 markedly prevented the formation of Alcian blue-positive cartilage nodules at a dose of $0.1 \mu \mathrm{M}$ or higher. The level of type II collagen transcripts in cells cultured in the presence or absence of $3 \mu \mathrm{M}$ Ki16425 was determined on day 14 (Fig. 8C), whilst the levels of type X collagen transcripts were determined on day 21 of culture (Fig. 8C). Thus, the Ki16425-treated ATDC5 cells expressed a markedly lower level of type II and type X collagen transcripts compared with untreated cells in control culture, indicating that Ki16425 exerts inhibitory effects 
on the progression of differentiation of ATDC5 cells.

In summary therefore, our current findings demonstrate that LPA plays a role in the behaviors of ATDC5 chondroprogenitor cells. In the course of the present study, Jeon et al. have also reported that LPA stimulates the differentiation of human adipose tissue-derived mesenchymal stem cells to myofibroblastic-like cells [47]. Their findings are compatible with the notion that LPA affects behaviors of tissue stem/progenitor cells. Our present study suggests a possibility that LPA plays an important role in the activation of chondroprogenitor cells. 


\section{Acknowledgments}

The authors are grateful to Prof. Junken Aoki (Graduate School of Pharmaceutical Sciences, Tohoku University) and Prof. Yoh Takuwa (Kanazawa University Graduate School of Medicine) for their helpful advice. This work was supported in part by Grants-in-aid from the Ministry of Education, Culture, Sports, Science, and Technology of Japan (Y.H.). 


\section{References}

1. Cancedda R, Descalzi Cancedda F, Castagnola P (1995) Chondrocyte differentiation. Int Rev Cytol 159:265-358

2. Hall BK, Miyake T (2000) All for one and one for all: condensations and the initiation of skeletal development. Bioessays 22:138-147

3. Kronenberg HM (2003) Developmental regulation of the growth plate. Nature $423: 332-336$

4. Mills GB, Moolenaar WH (2003) The emerging role of lysophosphatidic acid in cancer. Nat Rev Cancer 3:582-591

5. Alvarez SE, Milstien S, Spiegel S (2007) Autocrine and paracrine roles of sphingosine-1-phosphate. Trends Endocrinol Metab 18:300-307

6. Bachner D, Ahrens M, Betat N, Schroder D, Gross G (1999) Developmental expression analysis of murine autotaxin (ATX). Mech Dev 84:121-125

7. Ohuchi H, Hayashibara Y, Matsuda H, Onoi M, Mitsumori M, Tanaka M, Aoki J, Arai H, Noji S (2007) Diversified expression patterns of autotaxin, a gene for phospholipid-generating enzyme during mouse and chicken development. Dev Dyn 236:1134-1143

8. Umezu-Goto M, Kishi Y, Taira A, Hama K, Dohmae N, Takio K, Yamori T, Mills GB, Inoue K, Aoki J, Arai H (2002) Autotaxin has lysophospholipase D activity leading to tumor cell growth and motility by lysophosphatidic acid production. J Cell Biol 158:227-233

9. Tokumura A, Majima E, Kariya Y, Tominaga K, Kogure K, Yasuda K, Fukuzawa K (2002) Identification of human plasma lysophospholipase D, a lysophosphatidic 
acid-producing enzyme, as autotaxin, a multifunctional phosphodiesterase. J Biol Chem 277:39436-39442

10. van Meeteren LA, Ruurs P, Stortelers C, Bouwman P, van Rooijen MA, Pradere JP, Pettit TR, Wakelam MJ, Saulnier-Blache JS, Mummery CL, Moolenaar WH, Jonkers J (2006) Autotaxin, a secreted lysophospholipase D, is essential for blood vessel formation during development. Mol Cell Biol 26:5015-5022

11. Tanaka M, Okudaira S, Kishi Y, Ohkawa R, Iseki S, Ota M, Noji S, Yatomi Y, Aoki J, Arai H (2006) Autotaxin stabilizes blood vessels and is required for embryonic vasculature by producing lysophosphatidic acid. J Biol Chem 281:25822-25830

12. Pyne S, Pyne N (2000) Sphingosine 1-phosphate signalling via the endothelial differentiation gene family of G-protein-coupled receptors. Pharmacol Ther $88: 115-131$

13. Tigyi G, Parrill AL (2003) Molecular mechanisms of lysophosphatidic acid action. Prog Lipid Res 42:498-526

14. Contos JJ, Chun J (2000) Genomic characterization of the lysophosphatidic acid receptor gene, $\operatorname{lp}(\mathrm{A} 2) / \mathrm{Edg} 4$, and identification of a frameshift mutation in a previously characterized cDNA. Genomics 64:155-169

15.Spiegel S, Milstien S (2003) Sphingosine-1-phosphate: an enigmatic signalling lipid. Nat Rev Mol Cell Biol 4:397-407

16. Noguchi K, Ishii S, Shimizu T (2003) Identification of p2y9/GPR23 as a novel G protein-coupled receptor for lysophosphatidic acid, structurally distant from the Edg family. J Biol Chem 278:25600-25606

17. Kotarsky K, Boketoft A, Bristulf J, Nilsson NE, Norberg A, Hansson S, Owman C, Sillard R, Leeb-Lundberg LM, Olde B (2006) Lysophosphatidic acid binds to and 
activates GPR92, a G protein-coupled receptor highly expressed in gastrointestinal lymphocytes. J Pharmacol Exp Ther 318:619-628

18. Lee CW, Rivera R, Gardell S, Dubin AE, Chun J (2006) GPR92 as a new G12/13and Gq-coupled lysophosphatidic acid receptor that increases cAMP, LPA5. J Biol Chem 281:23589-23597

19. Tabata K, Baba K, Shiraishi A, Ito M, Fujita N (2007) The orphan GPCR GPR87 was deorphanized and shown to be a lysophosphatidic acid receptor. Biochem Biophys Res Commun 363:861-866

20. Pasternack SM, von Kugelgen I, Aboud KA, Lee YA, Ruschendorf F, Voss K, Hillmer AM, Molderings GJ, Franz T, Ramirez A, Nurnberg P, Nothen MM, Betz RC (2008) G protein-coupled receptor P2Y5 and its ligand LPA are involved in maintenance of human hair growth. Nat Genet 40:329-334

21. Yanagida K, Masago K, Nakanishi H, Kihara Y, Hamano F, Tajima Y, Taguchi R, Shimizu T, Ishii S (2009) Identification and characterization of a novel lysophosphatidic acid receptor, p2y5/LPA6. J Biol Chem 284:17731-17741

22. Murakami M, Shiraishi A, Tabata K, Fujita N (2008) Identification of the orphan GPCR, P2Y(10) receptor as the sphingosine-1-phosphate and lysophosphatidic acid receptor. Biochem Biophys Res Commun 371:707-712

23. Contos JJ, Fukushima N, Weiner JA, Kaushal D, Chun J (2000) Requirement for the lpA1 lysophosphatidic acid receptor gene in normal suckling behavior. Proc Natl Acad Sci U S A 97:13384-13389

24. Liu Y, Wada R, Yamashita T, Mi Y, Deng CX, Hobson JP, Rosenfeldt HM, Nava VE, Chae SS, Lee MJ, Liu CH, Hla T, Spiegel S, Proia RL (2000) Edg-1, the G protein-coupled receptor for sphingosine-1-phosphate, is essential for vascular 
maturation. J Clin Invest 106:951-961

25. Chae SS, Paik JH, Allende ML, Proia RL, Hla T (2004) Regulation of limb development by the sphingosine 1-phosphate receptor S1p1/EDG-1 occurs via the hypoxia/VEGF axis. Dev Biol 268:441-447

26. Kim MK, Lee HY, Park KS, Shin EH, Jo SH, Yun J, Lee SW, Yoo YH, Lee YS, Baek SH, Bae YS (2005) Lysophosphatidic acid stimulates cell proliferation in rat chondrocytes. Biochem Pharmacol 70:1764-1771

27. Kim KW, Ha KY, Lee JS, Nam SW, Woo YK, Lim TH, An HS (2009) Notochordal cells stimulate migration of cartilage end plate chondrocytes of the intervertebral disc in in vitro cell migration assays. Spine J 9:323-329

28. Facchini A, Borzi RM, Flamigni F (2005) Induction of ornithine decarboxylase in T/C-28a2 chondrocytes by lysophosphatidic acid: signaling pathway and inhibition of cell proliferation. FEBS Lett 579:2919-2925

29. Shukunami C, Shigeno C, Atsumi T, Ishizeki K, Suzuki F, Hiraki Y (1996) Chondrogenic differentiation of clonal mouse embryonic cell line ATDC5 in vitro: differentiation-dependent gene expression of parathyroid hormone (PTH)/PTH-related peptide receptor. J Cell Biol 133:457-468

30. Shukunami C, Ishizeki K, Atsumi T, Ohta Y, Suzuki F, Hiraki Y (1997) Cellular hypertrophy and calcification of embryonal carcinoma-derived chondrogenic cell line ATDC5 in vitro. J Bone Miner Res 12:1174-1188

31. Atsumi T, Miwa Y, Kimata K, Ikawa Y (1990) A chondrogenic cell line derived from a differentiating culture of AT805 teratocarcinoma cells. Cell Differ Dev 30:109-116

32. Chomczynski P, Sacchi N (1987) Single-step method of RNA isolation by acid 
guanidinium thiocyanate-phenol-chloroform extraction. Anal Biochem 162:156-159

33. Kimura T, Mattei M-G, Stevens JW, Goldring MB, Ninomiya Y, Olsen BR (1989) Molecular cloning of rat and human type IX collagen cDNA and localization of the $\alpha 1$ (IX) gene on the human chromosome 6. Eur J Biochem 179:71-78

34. Apte SS, Seldin MF, Hayashi M, Olsen BR (1992) Cloning of the human and mouse type $\mathrm{X}$ collagen genes and mapping of the mouse type $\mathrm{X}$ collagen gene to chromosome 10. Eur J Biochem 206:217-224

35. Hama K, Aoki J, Fukaya M, Kishi Y, Sakai T, Suzuki R, Ohta H, Yamori T, Watanabe M, Chun J, Arai H (2004) Lysophosphatidic acid and autotaxin stimulate cell motility of neoplastic and non-neoplastic cells through LPA1. J Biol Chem 279:17634-17639

36. Barrionuevo F, Taketo MM, Scherer G, Kispert A (2006) Sox9 is required for notochord maintenance in mice. Dev Biol 295:128-140

37. Deutsch U, Dressler GR, Gruss P (1988) Pax 1, a member of a paired box homologous murine gene family, is expressed in segmented structures during development. Cell 53:617-625

38. Contos JJ, Ishii I, Chun J (2000) Lysophosphatidic acid receptors. Mol Pharmacol 58:1188-1196

39. Zhang G, Contos JJ, Weiner JA, Fukushima N, Chun J (1999) Comparative analysis of three murine G-protein coupled receptors activated by sphingosine-1-phosphate. Gene 227:89-99

40. Ohta H, Sato K, Murata N, Damirin A, Malchinkhuu E et al. (2003) Ki16425, a subtype-selective antagonist for EDG-family lysophosphatidic acid receptors. Mol Pharmacol 64:994-1005 
41. Lee MJ, Jeon ES, Lee JS, Cho M, Suh DS, Chang CL, Kim JH (2008) Lysophosphatidic acid in malignant ascites stimulates migration of human mesenchymal stem cells. J Cell Biochem 104:499-510

42. Ridley AJ (2001) Rho GTPases and cell migration. J Cell Sci 114:2713-2722

43. Raftopoulou M, Hall A (2004) Cell migration: Rho GTPases lead the way. Dev Biol $265: 23-32$

44. Eichholtz T, Jalink K, Fahrenfort I, Moolenaar WH (1993) The bioactive phospholipid lysophosphatidic acid is released from activated platelets. Biochem $\mathbf{J}$ 291:677-680

45. Sano T, Baker D, Virag T, Wada A, Yatomi Y, Kobayashi T, Igarashi Y, Tigyi G (2002) Multiple mechanisms linked to platelet activation result in lysophosphatidic acid and sphingosine 1-phosphate generation in blood. $\mathrm{J}$ Biol Chem $277: 21197-21206$

46. Shukunami C, Akiyama H, Nakamura T, Hiraki Y (2000) Requirement of autocrine signaling by bone morphogenetic protein-4 for chondrogenic differentiation of ATDC5 cells. FEBS Lett 469:83-87

47. Jeon ES, Moon HJ, Lee MJ, Song HY, Kim YM, Cho M, Suh DS, Yoon MS, Chang CL, Jung JS, Kim JH (2008) Cancer-derived lysophosphatidic acid stimulates differentiation of human mesenchymal stem cells to myofibroblast-like cells. Stem Cells 26:789-797 


\section{Figure legends}

FIG 1. The expression pattern of $\mathrm{LPA}_{1}$ in E10.5 mouse embryos. In situ hybridization was carried out with type II collagen antisense (A; Col II AS), Sox9 antisense (C; Sox9 AS), Paxl antisense (D; Pax1 AS), $L P A_{1}$ antisense (E; LPA1 AS), ATX antisense (F; ATX AS), $L P A_{1}$ sense (G; LPA1 S), and $A T X$ sense (H; ATX S) riboprobes and the semi-serial section was stained with hematoxylin-eosin (B, HE). Transverse sections of an E10.5 mouse embryo were made at thoracic levels. Arrows in panel A, C, and E indicate the cartilaginous elements of vertebrae such as neural arch and rib. Dotted circles in panel D and E indicate Paxl-positive regions. drg; dorsal root ganglia, nt; neural tube, n; notochord, da; dorsal aorta. Bars, $100 \mu \mathrm{m}$.

FIG. 2. The expression pattern of $\mathrm{LPA}_{1}$ in E11.5 mouse embryos. In situ hybridization was carried out with $\mathrm{LPA}_{1}$ antisense (A; LPA1 AS), LPA1 sense (B; LPA1 S) and type II collagen antisense (C; Col II AS) riboprobes and semi-serial sagittal sections of an E11.5 mouse embryo. (D) A semi-serial section stained with hematoxylin-eosin (HE). (E-G) Magnified views of the boxed areas in e, f, and g, respectively. In each panel, the anterior side is on the right, and posterior is on the left. The arrowheads in E-G indicate the regions expressing $\mathrm{LPA}_{1}$ transcripts. Bars, $1.25 \mathrm{~mm}$ in A-D; $200 \mu \mathrm{m}$ in E-G.

FIG. 3. Expression of lysophospholipid receptors in ATDC5 cells and their temporal changes during chondrogenic differentiation. Total RNA $(15 \mu \mathrm{g})$ isolated from ATDC5 cells on the indicated day of culture was subjected to northern blot analysis with probes for LPA receptors $\left(\mathrm{LPA}_{1-3}\right)$ and $\mathrm{S} 1 \mathrm{P}$ receptors $\left(\mathrm{S}_{1} \mathrm{P}_{1-3}\right)$. The same blot was also hybridized with probes for type II collagen (Col II) and type $\mathrm{X}$ collagen (Col X). 
Aliquots of total RNA (15 $\mu \mathrm{g})$ isolated from testis, lung, kidney, and rib cartilage were also subjected to northern blot analysis as a positive control for the expression of LPA 1 (testis and lung), $\mathrm{LPA}_{2-3}$ (testis and kidney) or $\mathrm{S}_{1-3}$ (lung). The positions of $28 \mathrm{~S}$ and 18S ribosomal RNAs are indicated. The bottom panels show ethidium bromide-stained gels. Relative expression levels of $\mathrm{LPA}_{1}$ were determined by densitometric analysis and were normalized to the level on day 3 . The relative levels were 1.0 on day $3,1.2$ on day $7,0.7$ on day $14,0.7$ on day $17,1.0$ on day 26 , and 0.9 on day 42 .

FIG. 4. Effects of LPA and S1P on the growth of undifferentiated ATDC5 chondroprogenitor cells in confluent cultures. (A, B) The rate of DNA synthesis was assessed by BrdU incorporation. Cells were grown to confluence in 96-multiwell plates for three days in DMEM/F12 containing 5\% FBS and ITS. The cells were then incubated with DMEM/F12 containing $0.1 \%$ BSA in the absence $(\square)$ or presence of $100 \mathrm{ng} / \mathrm{ml}$ PTX for $24 \mathrm{~h}$, treated with the indicated concentrations of LPA (A) or S1P (B) for an additional $24 \mathrm{~h}$, and labeled with $1 \mathrm{nmol} / \mathrm{ml} \mathrm{BrdU}$ for the last $4 \mathrm{~h}$. The incorporation of BrdU into DNA was then determined. The values shown are the mean \pm SD of triplicate assays. Two independent experiments were carried out and gave similar results. (C) Cells were plated and grown in 12-multiwell plates to confluence in DMEM/F12 containing 5\% FBS. The cells were then preincubated with DMEM/F12 containing $0.3 \%$ FBS for $24 \mathrm{~h}$. The medium was then replaced by the same medium with test samples. After incubation for $36 \mathrm{~h}$, cells were counted with a hemocytometer after trypsinization. In the control wells treated with vehicle alone, the cell number was $16.2 \pm 2.0 \times 10^{4}$ cells/well $(100 \pm 12 \%)$. The values shown are the mean \pm SD of triplicate assays. (D, E) Activation of the ERK1/2 signaling in cells treated with LPA. 
Cells were grown to confluence in 12-multiwell plates, and were preincubated in DMEM/F12 containing $0.1 \%$ BSA for $6 \mathrm{~h}$. In some experiments, the cells were preincubated with $100 \mathrm{ng} / \mathrm{ml}$ PTX for the last $4 \mathrm{~h}$. Cells were then incubated with 0.1 $\mu \mathrm{M}$ LPA for the indicated time in (D) or with various concentration of LPA for $5 \mathrm{~min}$ in the presence and absence of PTX or Ki16425 in (E). Phosphorylated ERK1/2 (p-ERK1/2) and total ERK1/2 were visualized by western blotting.

FIG. 5. Effects of LPA and S1P on the migration of undifferentiated ATDC5 chondroprogenitor cells. (A) Cells were plated at $5 \times 10^{4}$ cells/well on the top well of a migration chamber coated with type I collagen, and then allowed to migrate for $4 \mathrm{~h}$ toward the bottom well containing various concentrations of LPA $(\square)$ or S1P $(\boldsymbol{\square})$ in DMEM/F12 containing $0.1 \%$ BSA and ITS. The numbers of migrated cells shown are the mean $\pm \mathrm{SD}$ of triplicate assays. (B) Cells were pre-incubated in DMEM/F12 containing $0.1 \%$ BSA and ITS in the absence $(-)$ or presence $(+)$ of PTX $(100 \mathrm{ng} / \mathrm{ml})$ for $4 \mathrm{~h}$ before harvesting. The transwell migration of cells was determined in the absence $(-)$ or presence $(+)$ of $0.1 \mu \mathrm{M}$ LPA in the bottom well. Values shown are the means $\pm \mathrm{SD}$ of quintuplicate assays. (C) Cells were resuspended in DMEM/F12 containing $0.1 \%$ BSA and ITS, then preincubated with selective inhibitors of PI3K (LY294002; LY, 20 $\mu \mathrm{M}), \operatorname{MEK} 1 / 2$ (U0126; U, $10 \mu \mathrm{M})$, and ROCK (Y-27632; Y, $10 \mu \mathrm{M})$ for 30 min prior to seeding onto transwells. The transwell migration of cells was performed in the absence $(-)$ or presence $(+)$ of $0.1 \mu \mathrm{M}$ LPA in the bottom well. Values shown are the means \pm SD of quintuplicate assays. (D) The inhibition of LPA-stimulated migration of cells by Ki16425. The transwell migration of cells toward $0.1 \mu \mathrm{M}$ LPA was determined in the 
presence of various concentrations of Ki16425 in the top well. Values shown are the mean \pm SD of triplicate assays. (E) Cells grown on glass chamber slides were pre-incubated for $6 \mathrm{~h}$ in DMEM/F12, and stimulated without (control) or with $0.1 \mu \mathrm{M}$

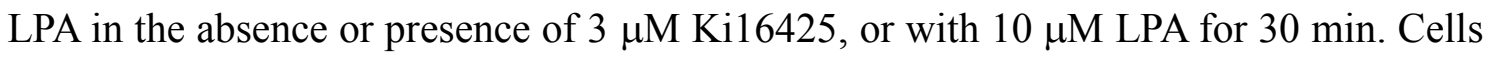
were then fixed, permeabilized and stained for actin fibers (red) and focal adhesion (green) using phalloidin and an antibody to paxillin, respectively. Bars, $20 \mu \mathrm{m}$. (F) Activation of RhoA by LPA. Cells were serum-starved in DMEM/F12 containing $0.1 \%$ BSA for $6 \mathrm{~h}$ and then stimulated with LPA for $2 \mathrm{~min}$. Cell lysates were analyzed for active RhoA (GTP-RhoA) by an affinity pull-down assay using Rhotekin-RBD agarose beads. Bound proteins were then subjected to western blot analysis using anti-RhoA mouse monoclonal antibody. Aliquots of cell lysates were subjected to western blotting with the anti-RhoA antibody for the assessment of total RhoA levels in cells, which remained constant with or without LPA treatments.

FIG. 6. Role of $\mathrm{LPA}_{1}$ signaling in the LPA-induced migration of ATDC5 chondroprogenitor cells. (A) Knockdown of $\mathrm{LPA}_{1}$ expression by siRNA. Cells were transfected with non-targeting siRNA (ctrl) or LPA1 siRNA by electroporation. Total RNA was extracted from the cells $24 \mathrm{~h}$ after transfection, and the expression levels of $L P A_{1}$ (30 cycles), $L A_{2}$ (35 cycles), $L P A_{3}$ (35 cycles), and GAPDH (30 cycles) transcripts were analyzed by RT-PCR. GAPDH was used as an internal control. (B) Cells were transfected with non-targeting (control) siRNA $(\square)$ or LPA1 siRNA ( $\square$ ). 24 $\mathrm{h}$ after transfection, cells were harvested, resuspended in DMEM/F12 containing $0.1 \%$ BSA and ITS. The transwell migration of cells was performed in the absence (-) or 
presence $(+)$ of $0.1 \mu \mathrm{M}$ LPA in the bottom well. Values shown are the means $\pm \mathrm{SD}$ of quintuplicate assays.

FIG. 7. Effects of different growth factors and FBS on the migration of undifferentiated ATDC5 chondroprogenitor cells. (A) The transwell migration of cells toward 5\% FBS or $0.1 \mu \mathrm{M}$ LPA was assessed in the absence $(\square)$ or presence $(\boldsymbol{\square})$ of $3 \mu \mathrm{M}$ Ki16425 in the top well. Values are the means \pm SD of quintuplicate assays. (B) The transwell migration of cells toward $100 \mathrm{ng} / \mathrm{ml}$ IGF-I, $25 \mathrm{ng} / \mathrm{ml}$ PDGF-BB or $20 \mathrm{ng} / \mathrm{ml} \mathrm{FGF2} \mathrm{was}$ assessed in the absence or presence of $3 \mu \mathrm{M}$ Ki16425 in the top well. Values are the means \pm SD of triplicate assays. (C) Transwell migration of cells toward $25 \mathrm{ng} / \mathrm{ml}$ PDGF-BB was determined in the presence of various concentrations of LPA ( $\square$ ) or S1P $(\boldsymbol{\square})$ in the bottom well. Values are the means \pm SD of triplicate assays.

Fig. 8. Effects of the LPA receptor antagonist Ki16425 on chondrogenic differentiation of ATDC5 cells. (A) Cells were plated at $2 \times 10^{4}$ cells per well in 24-multiwell plates and allowed to differentiate by culturing for 17 days in DMEM/F12 medium containing 5\% FBS and ITS. From day 3, cells were cultured in the same medium containing different concentrations $(\mu \mathrm{M})$ of Ki16425. Cells were fixed on day 17 and stained with Alcian blue. The figure represents one of three independent experiments that gave similar results. DMSO (at a final concentration of $0.1 \%$ ) that was used as a solvent for Ki16425 had no significant effects alone on the differentiation of ATDC5 cells. (B) Quantitative analysis of Alcian blue-positive nodules formed in the ATDC5 cell cultures shown in panel A. Images of the wells stained by Alcian blue were taken and the stained 
area in each well was analyzed using NIH image. Values are expressed as a percentage of the total stained area of the well cultured with vehicle alone in the absence of Ki16425 (denoted as $0 \mu \mathrm{M}$ ), and are means \pm SD of quintuple assays. (C) Effects of Ki16425 on the expression of type II and type X collagen in ATDC5 cells. Cells were plated at $6 \times 10^{4}$ cells/well in 6 -multiwell plates and allowed to differentiate in DMEM/F12 containing 5\% FBS and ITS. After the culture reached confluence on day 3, cells were cultured in the absence or presence of $3 \mu \mathrm{M}$ Ki16425 in DMEM/F12 containing 5\% FBS and ITS. Total RNA $(5 \mu \mathrm{g})$ isolated from ATDC5 cells on day 14 and day 21 was subjected to northern blot analysis using probes for type II collagen ( Col II) and type X collagen $(\mathrm{Col} X)$, respectively. The positions of $28 \mathrm{~S}$ and $18 \mathrm{~S}$ ribosomal RNAs are indicated. The bottom panels show the ethidium bromide-stained gels. 
Fig. 1

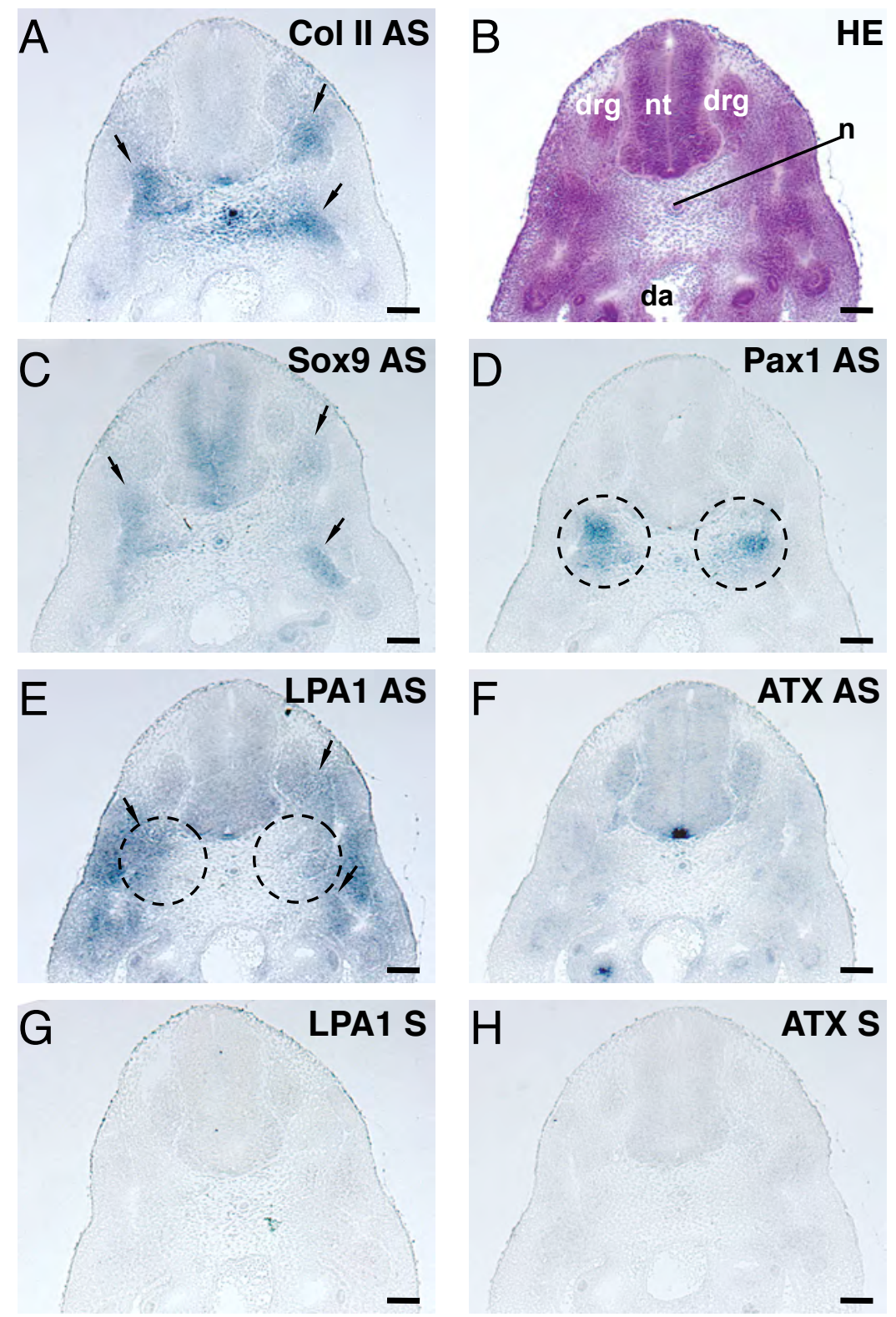



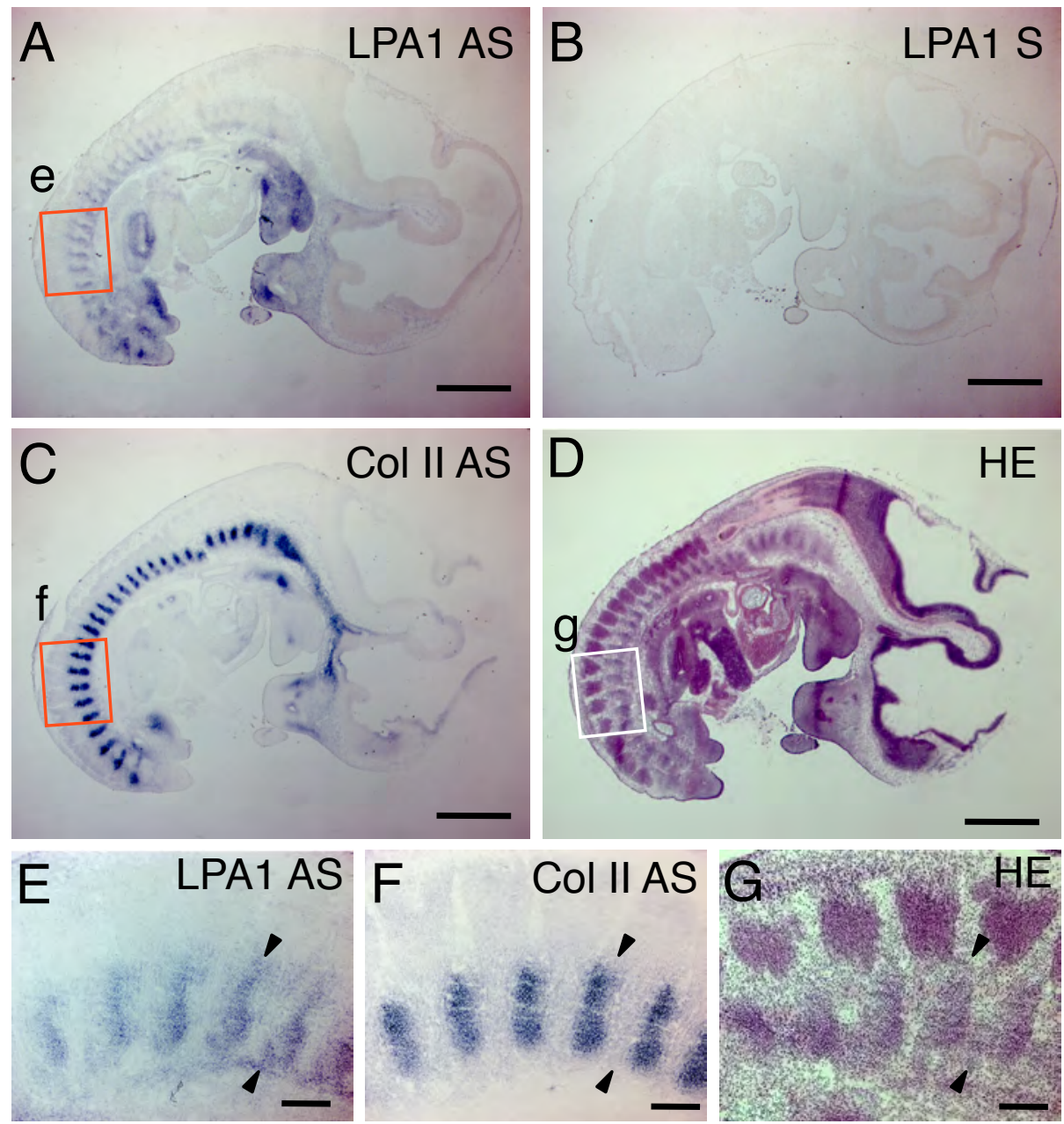

Col II AS

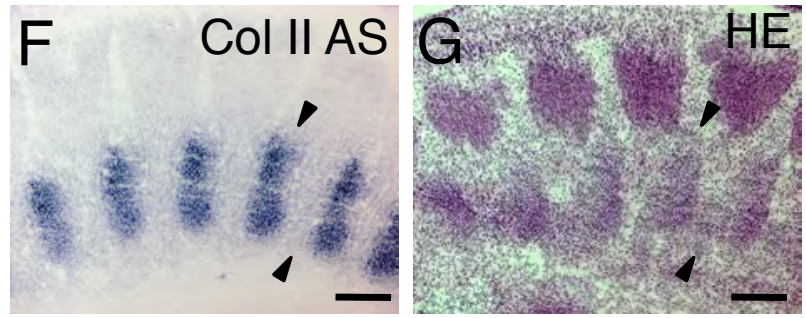


Fig. 3

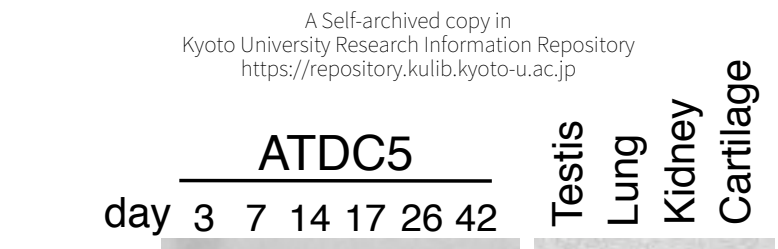

$L P A_{1}$

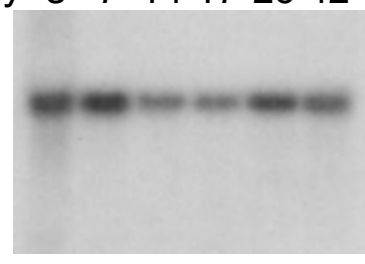

$-18 S$

$\angle P A_{2}$

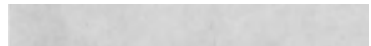

$-28 S$

- 18S

$-28 S$

$L P A_{3}$

$L P A_{3}$
$S 1 P_{1}$

$S 1 P_{1}$
$S 1 P_{2}$

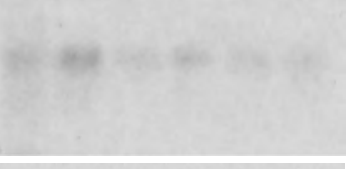

$-285$

$-18 S$

$-28 S$

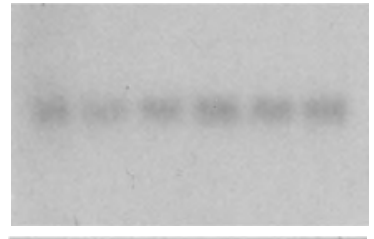

-

$-18 S$

$-28 S$

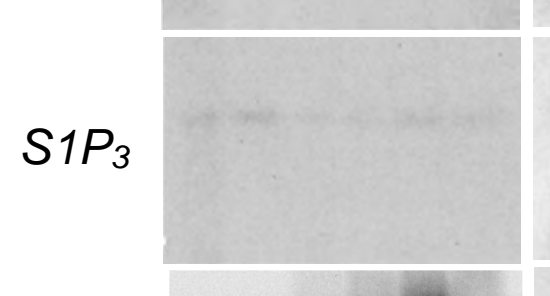

$-18 S$

$-28 S$

$\mathrm{S}_{3} \mathrm{P}_{3}$

Col II

ColX

$\mathrm{Et}-\mathrm{Br}$

$-18 S$

$-28 S$

- 18S

- 28S
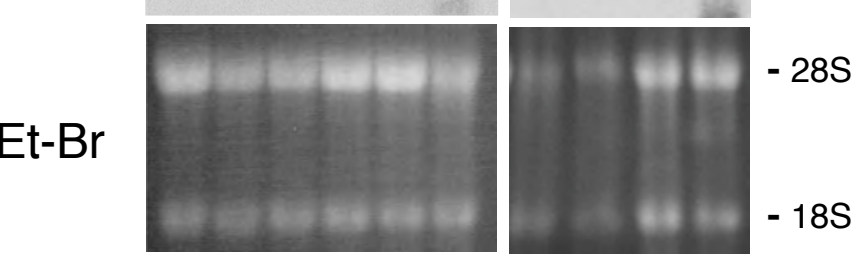
A

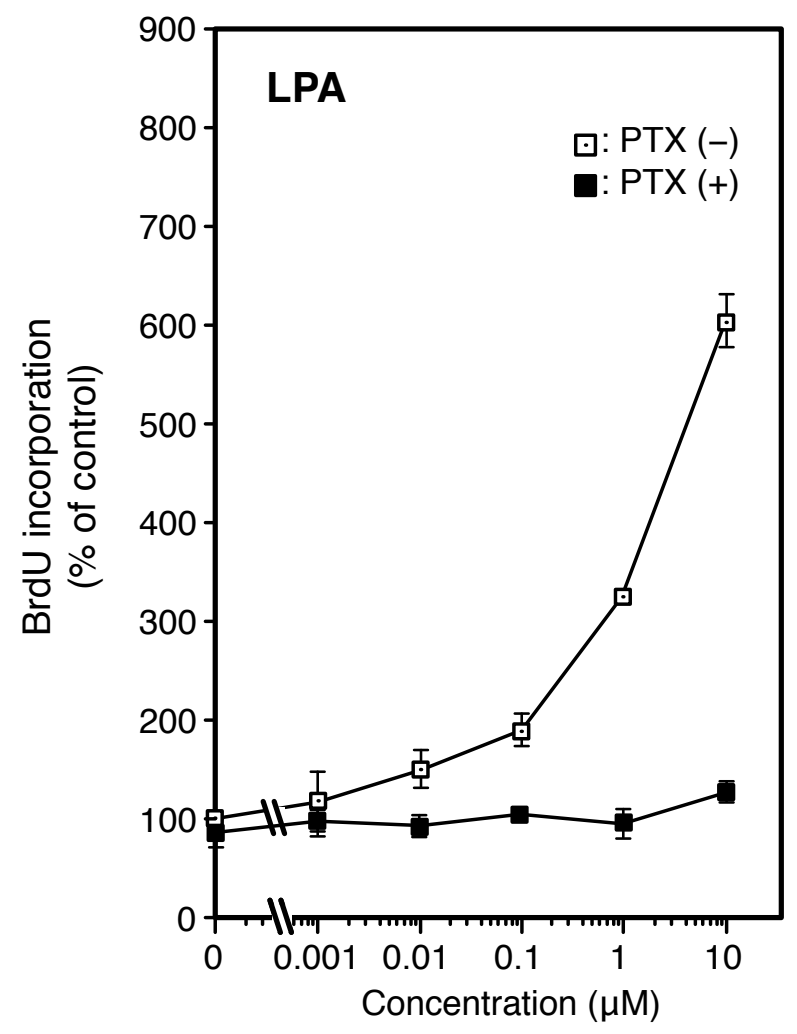

B

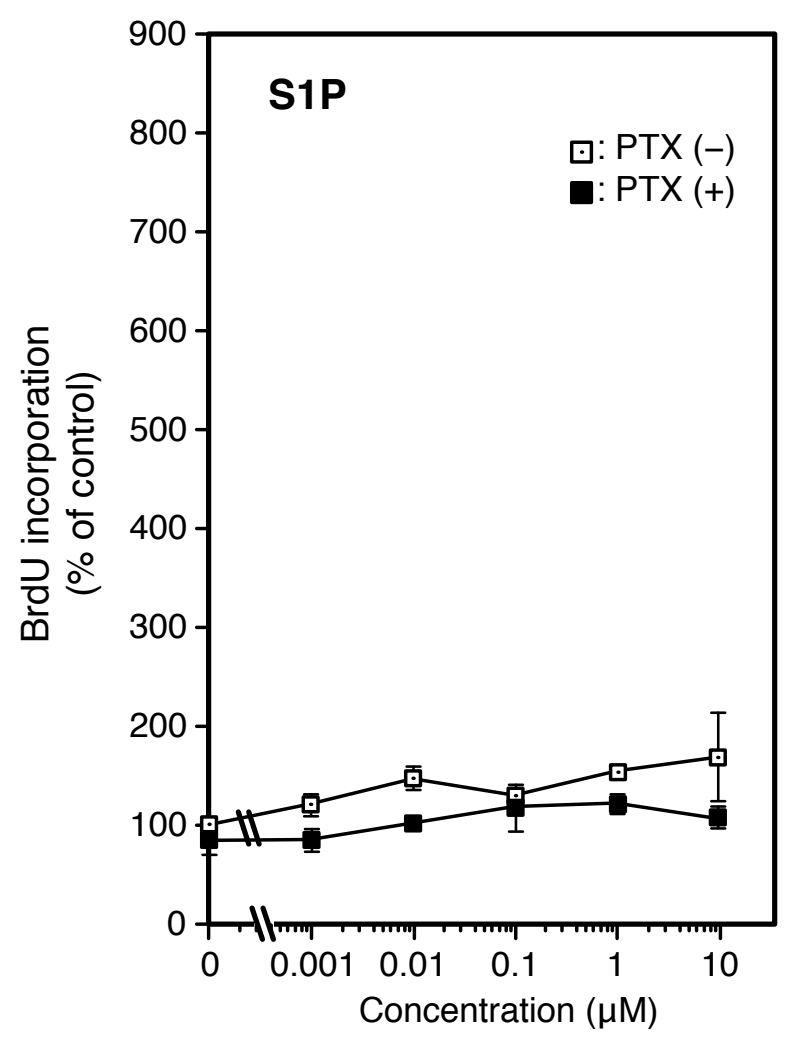

C

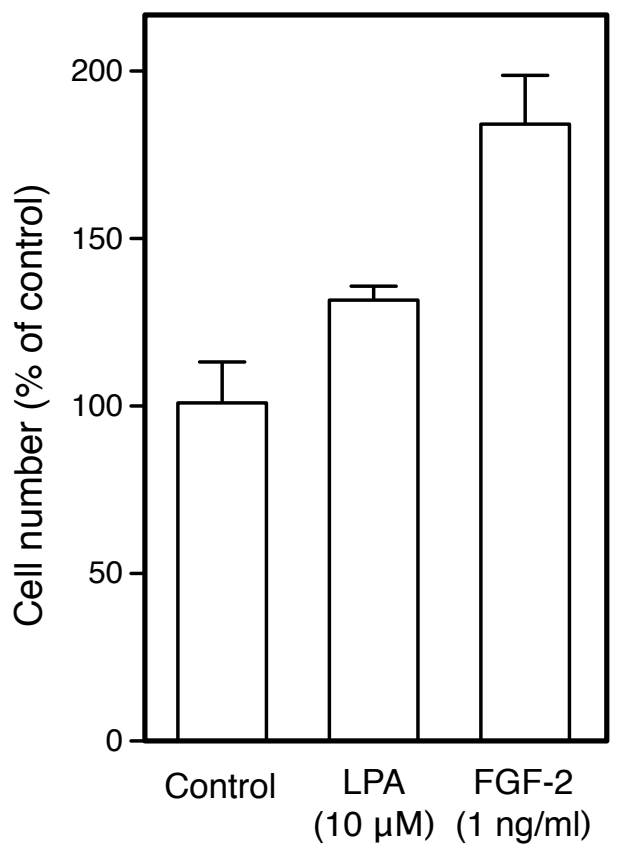

D

$\begin{array}{lllllll}\text { LPA }(\mu \mathrm{M}) & 0 & 0.1 & 0.1 & 1 & 0.1 & 0.1\end{array}$ $\begin{array}{lllllll}\text { Time }(\min ) & 0 & 5 & 10 & 10 & 20 & 30\end{array}$

\section{p-ERK1/2}

\section{ERK1/2}

E

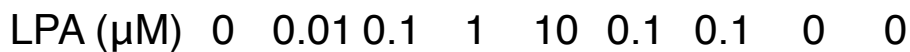
FGF-2 $(1 \mathrm{ng} / \mathrm{ml})-\quad-\quad-\quad-\quad-++$ PTX (100 ng/ml) - $-\quad-\quad-\quad+--+$

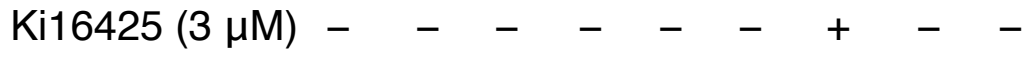

p-ERK1/2

ERK1/2 
A

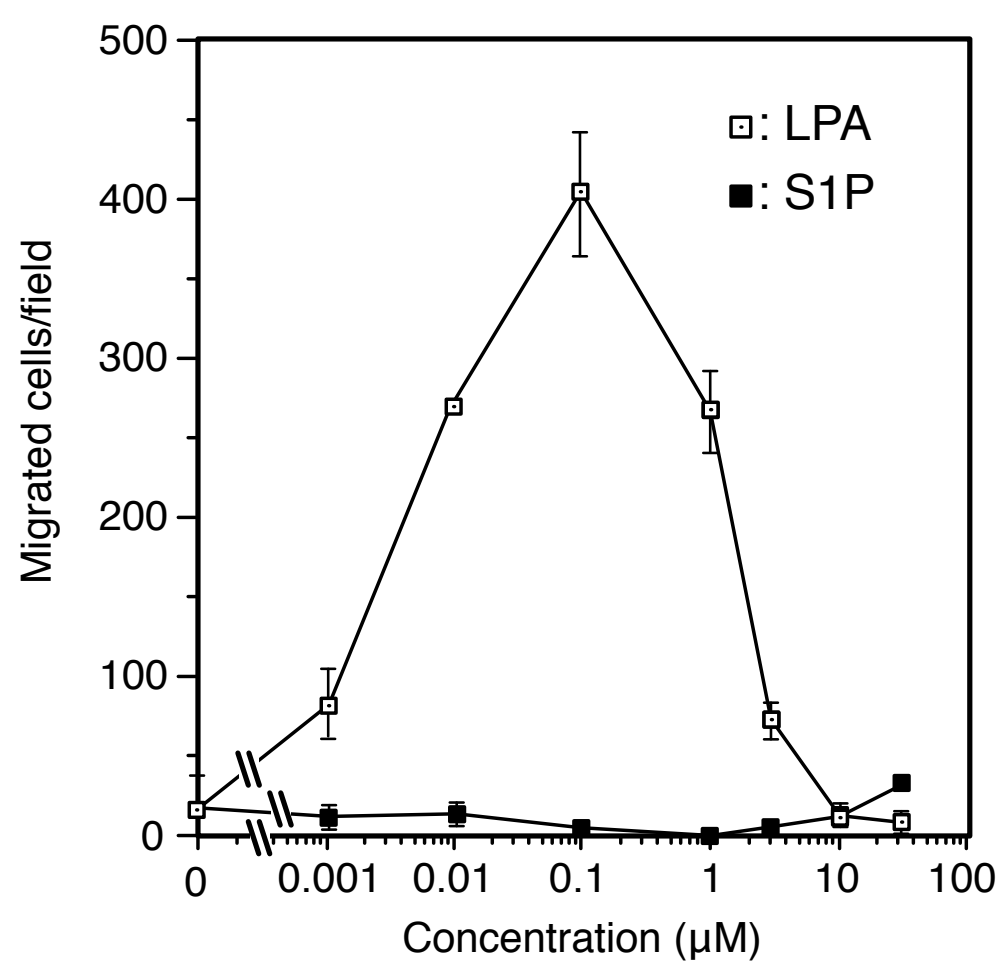

B

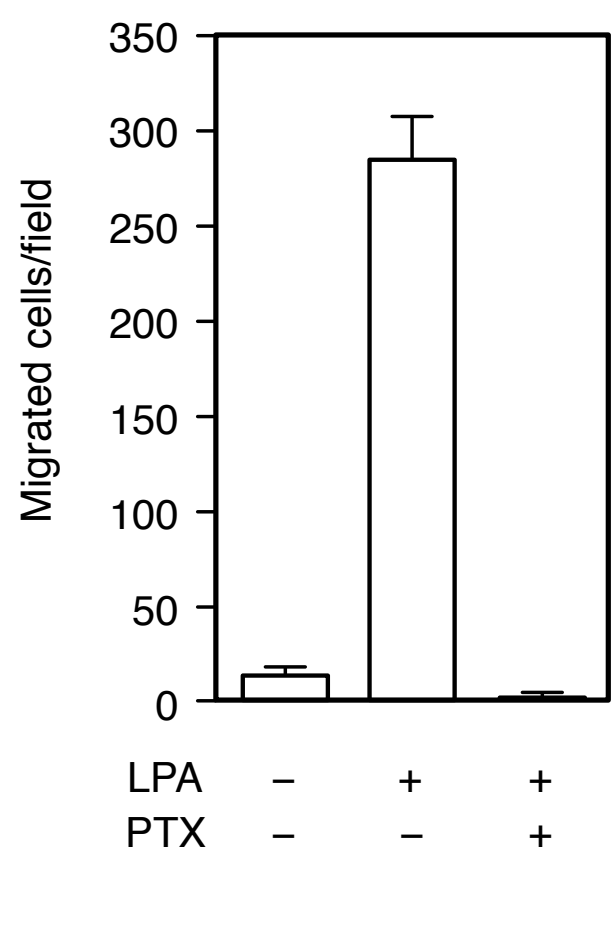

C

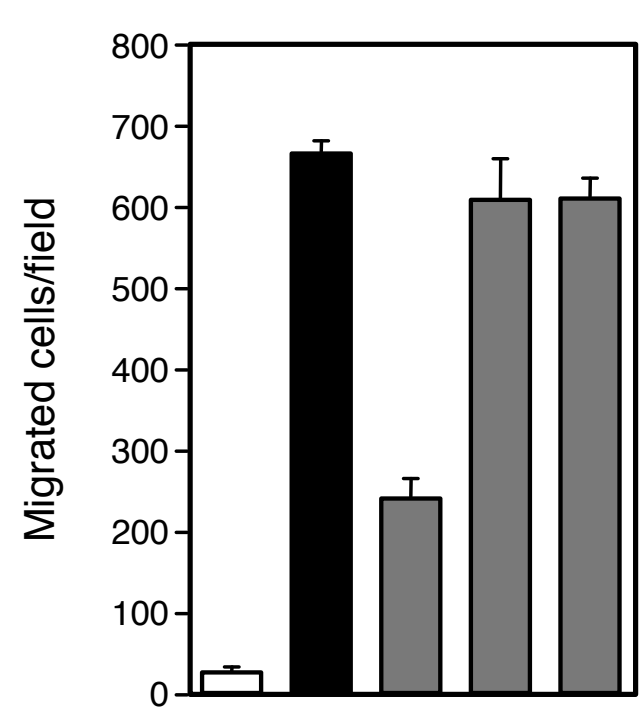

LPA - + + + + Inhibitor - - LY U Y

D

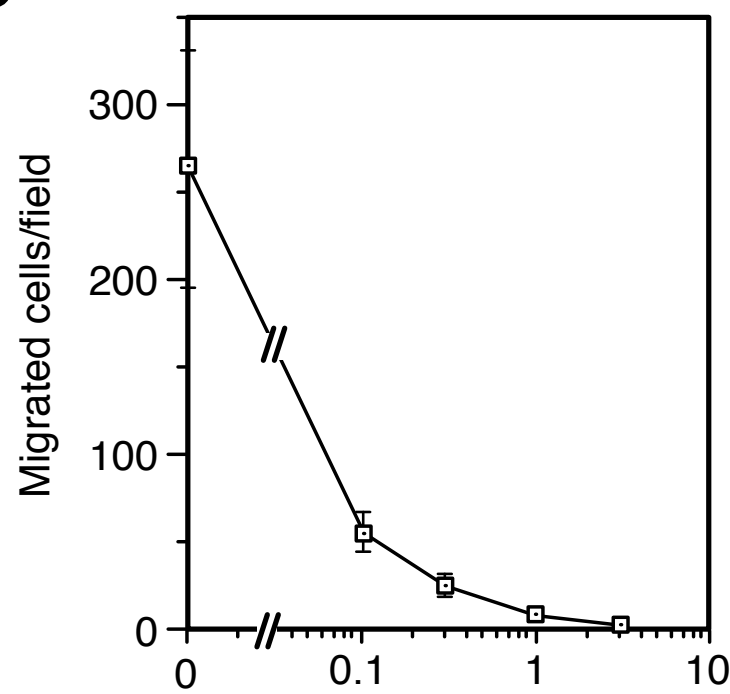

Concentration of Ki16425 ( $\mu \mathrm{M})$
E
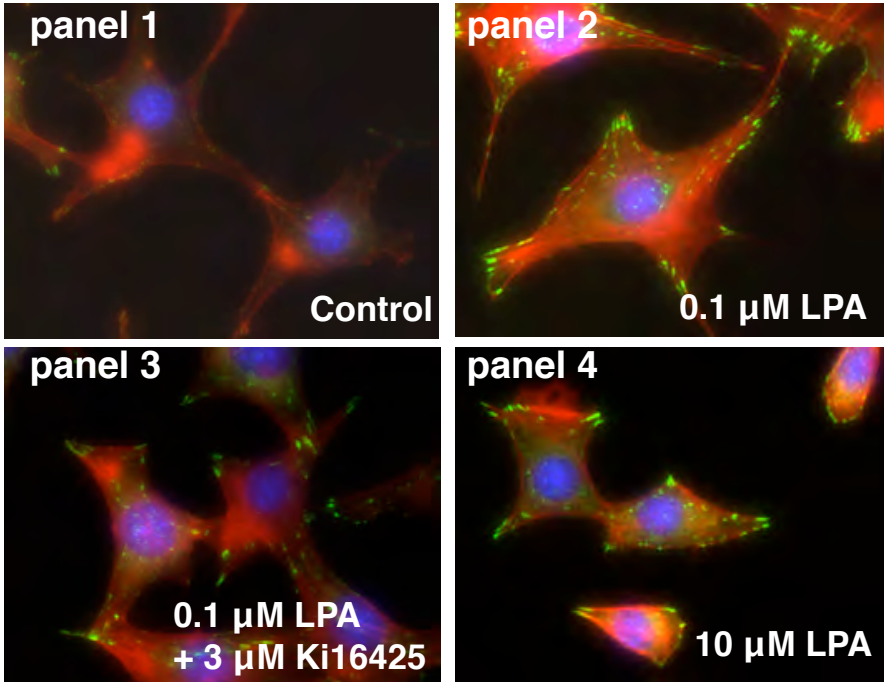

$\mathbf{F}$

$$
\operatorname{LPA}(\mu \mathrm{M}) \quad 0 \quad 0.1 \quad 1 \quad 10
$$

Affinity pull-down: GTP-RhoA

Immunoblot: RhoA 
Fig. 6

A

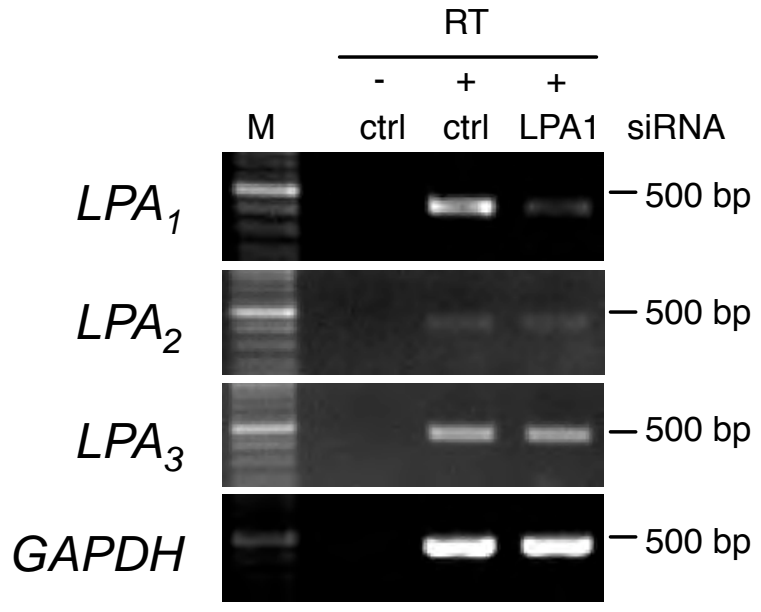

B

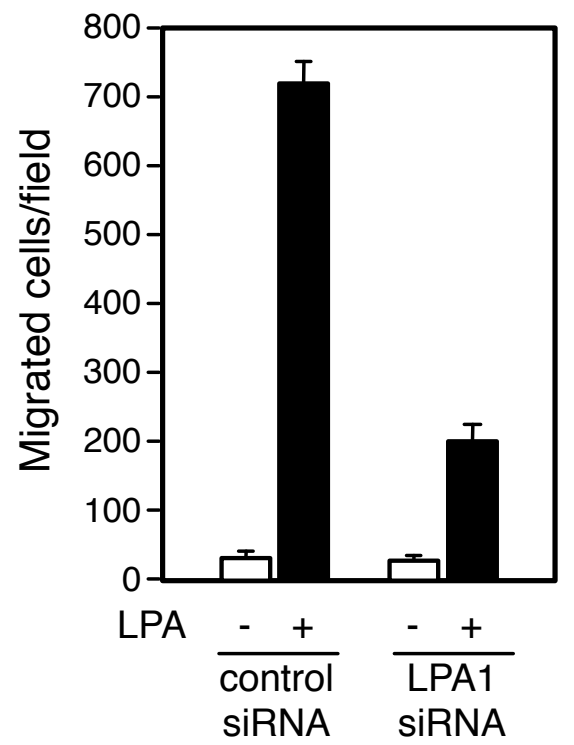


Fig. 7

\section{A}

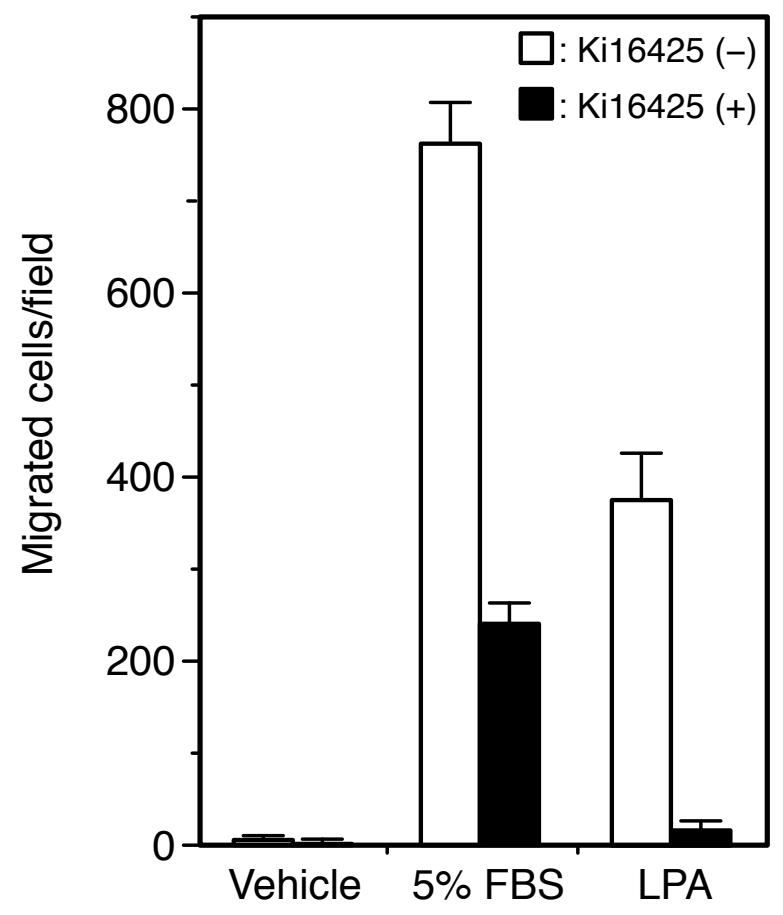

B

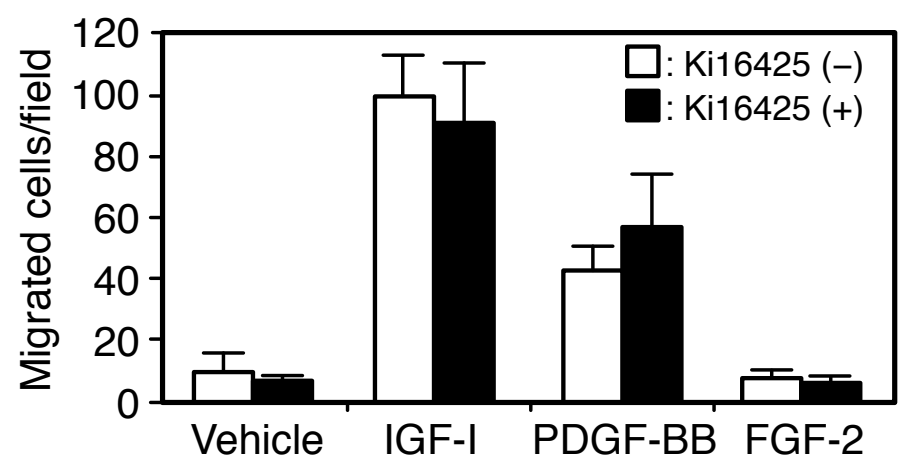


Fig. 8

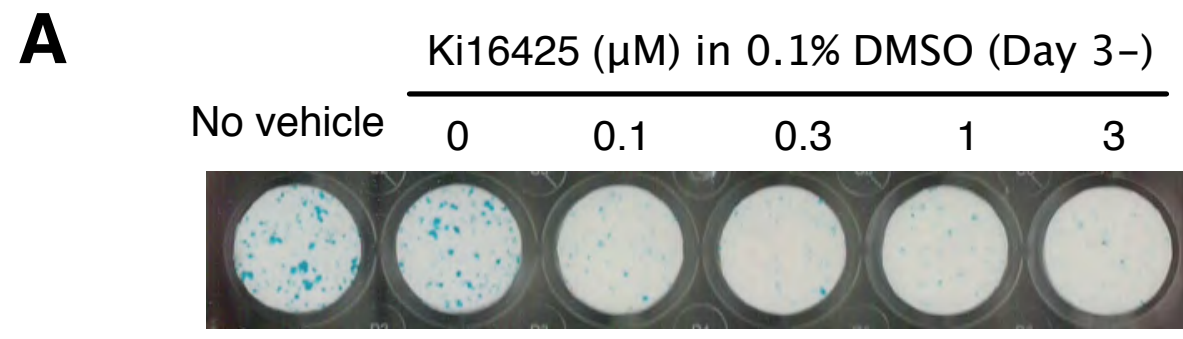

B

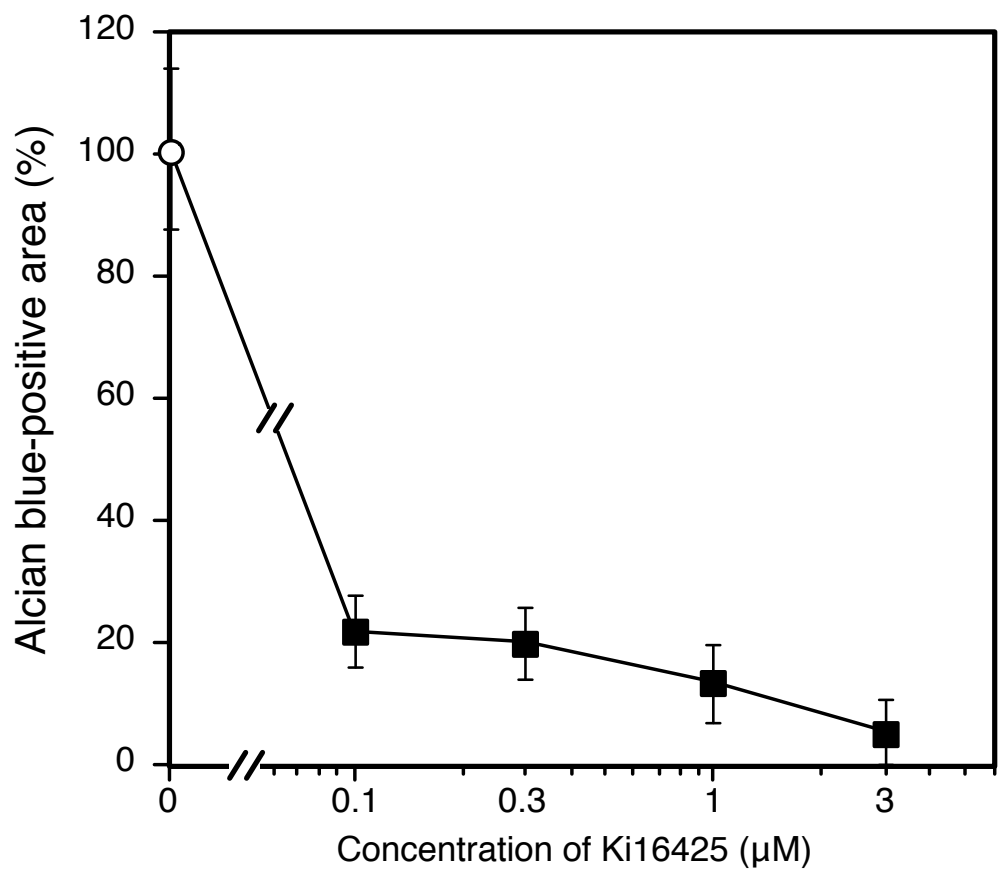

C
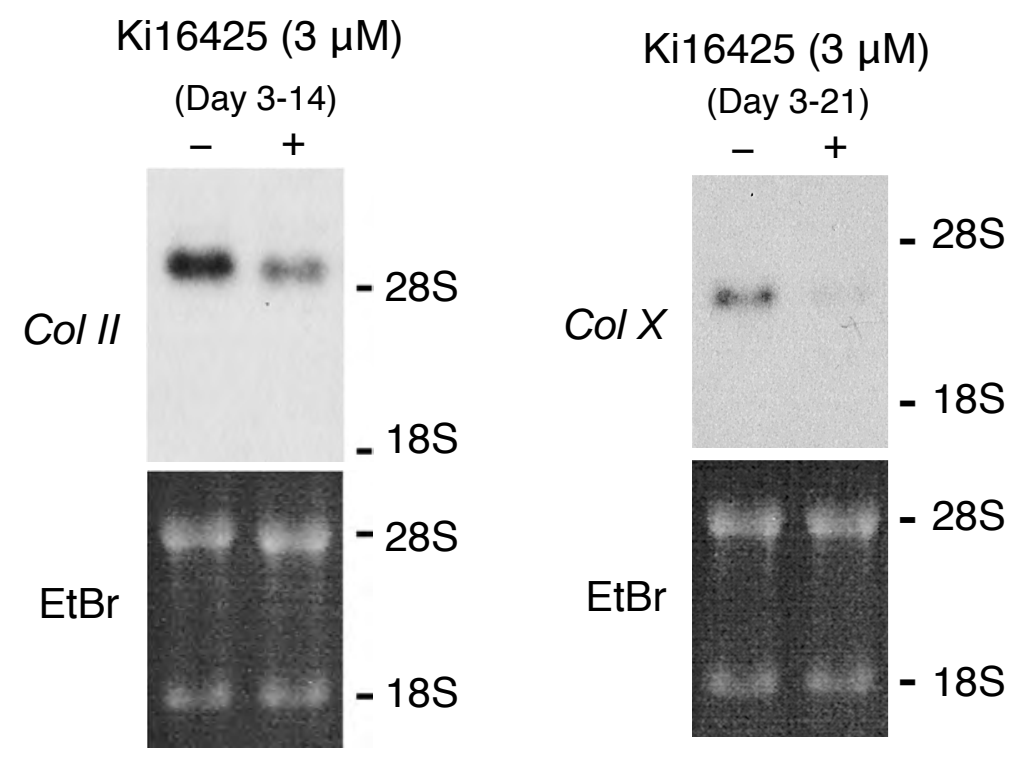
Table 1. List of primers used for RT-PCR

\begin{tabular}{lll}
\hline Gene & Forward primer (5' to 3') & Reverse primer (5' to 3') \\
\hline LPA $_{1}$ & GAACACAGTGAGCAAGCTGG & CATAGCAGAGTTGAACTCGGC \\
LPA $_{2}$ & GCATGGCTCTTCAACACTCC & AGTTCAAGGCCATCCTCACC \\
LPA $_{3}$ & TATCTCCACACACCAGTGGC & AGGTGAGGACGCTTAACAGC \\
$\mathrm{S}_{1} P_{1}$ & CATCTGCTGCTTCATCATCC & TAGTGCTTGTGGTAGAGCGG \\
${\mathrm{S} 1 \mathrm{P}_{2}}$ & GAACAGCAAGTTCCACTCAGC & TATGCATGCCTCTCTCCAGG \\
${\mathrm{S} 1 \mathrm{P}_{3}}$ & GCGTGTTCCTTCTGATTGG & AATAGGTGTGGCTGCAGAGC \\
\hline
\end{tabular}

